JPPUMA: Jurnal Ilmu Pemerintahan dan Sosial Politik UMA (Journal of Governance and Political Social UMA),

6 (2) (2018): 132-141, DOI: 10.31289/jppuma.v6i2.1895

JPPUMA: Jurnal Ilmu Pemerintahan dan Sosial Politik UMA

(Journal of Governance and Political Social UMA)

Available online http://ojs.uma.ac.id/index.php/jppuma

\title{
Konseptualisasi Hak-Hak Politik dalam Sejarah Periodesasi Demokrasi
}

\section{Conceptualization of Political Rights in History of Democracy Perioditation}

\author{
R. Samidi \& Suharno \\ Program Pascasarjana, Universitas Negeri Yogyakarta, Indonesia
}

Diterima September 2018; Disetujui Desember 2018; Dipublikasikan Desember 2018

\begin{abstract}
Abstrak
Masyarakat golongan ekonomi bawah merupakan sasaran strategis bagi aktor politik untuk melancarkan aksi dan janji politik yang mengisyaratkan kepentingan. Untuk mengantisipasi hal tersebut diperlukan upaya meningkatkan kesadaran berpolitik masyarakat yang tidak hanya terbatas pada tindakan dan aktivitas politik, melainkan juga mencakup pengetahuan tentang politik yang dapat dimulai dengan memahami hakikat hak-hak politik dengan benar dan komprehensif. Oleh karena itu, tujuan penulisan artikel ini adalah untuk mendeskripsikan konseptualisasi hak-hak politik warga negara yang dirunut berdasarkan sejarah penggunaan konsep demokrasi dari berbagai periode waktu. Metode yang digunakan untuk menyusun artikel ini adalah studi kepustakaan dan data dianalisis dengan model analisis induktif. Hasil yang diperoleh dari penulisan artikel ini adalah konseptualisasi penggunaan hak politik berdasarkan sejarah penggunaan demokrasi yang dimulai dari masa Yunani Kuno (abad 6 sampai 3 SM) sampai dengan abad ke-20.

Kata Kunci: Konseptualisasi, Hak-hak Politik, Periodesasi Demokrasi.
\end{abstract}

\section{Abstract}

The lower economic community is a strategic target for political actors to launch political actions and promises that signal interest. To anticipate this, efforts needed to increase an awareness of community politics which is not only limited to political actions and activities, but also includes knowledge about politics that can be started by understanding the nature of political rights correctly and comprehensively. Therefore, the purpose of writing this article is to describe the conceptualization of citizens' political rights traced based on the history of the use of the concept of democracy from various periods of time. The method used to compile this article is library research and data analyzed by inductive analysis models. The results obtained from the writing of this article are the conceptualization of the use of political rights based on the history of the use of democracy which began from the time of Ancient Greece (6th to 3rd century BC) until the 20th century.

Keywords: Conceptualization, Political Rights, Periodization of Democracy.

How to Cite: Samidi, R \& Suharno (2018). Konseptualisasi Hak-Hak Politik Dalam Sejarah Periodesasi Demokrasi. JPPUMA: Jurnal Ilmu Pemerintahan dan Sosial Politik UMA (Journal of Governance and Political Social UMA), 6 (2): 132-141.

*Corresponding author:

E-mail: rsamidi_90.2017@student.uny.ac.id
ISSN 2549-166o (Print)

ISSN 2550-1305 (Online) 


\section{PENDAHULUAN}

Berbicara tentang demokrasi, kata kunci yang muncul dari istilah tersebut adalah warga negara, kekuasaan, dan lembaga negara. Poin penting dalam konsep demokrasi terletak pada pemerintahan sebagai kekuasaan yang mengandung pengertian politik, dan rakyat sebagai warga negara yang memegang kekuasaan atau menjalankan pemerintahan. Pemerintah sebagai konsep kekuasaan dibangun atas dasar persamaan politik yang kemudian dijalankan dalam rangka menciptakan terselenggaranya kebebasaan politik warga negara. Politik merupakan segala sesuatu yang bersangkutan dengan kekuasaan, pemerintahan, proses memerintah dan bentuk organisasi pemerintah, lembaga atau institusi, tujuan negara atau pemerintahan negara (Sunarso, 2007). Sebagai pilar demokrasi, politik sangat sensitif terhadap perubahan dinamika dalam masyarakat. Untuk mewujudkan kehidupan politik yang stabil, maka negara harus dapat membuat kontrol dalam menyeimbangkan pemenuhan hak dan kewajiban politik warga negara. Kewajiban politik dapat dipenuhi melalui upaya warga negara untuk mentaati aturanaturan pemerintah sebagai produk dari kebijakan politik. Sedangkan hak politik dapat diidentifikasi melalui tindakantindakan warga negara untuk ikut terlibat dalam kegiatan politik, seperti hak untuk memilih atau dipilih sebagai respresentatif masyarakat dalam kursi pemerintahan.

Politik memiliki pengaruh luas yang menyangkut berbagai bidang, salah satunya ialah masalah ekonomi. Apabila kekuasaan hanya digunakan untuk kepentingan pribadi maupun kelompok, maka akan mengarah pada politik tidak sehat yang berkontribusi dalam menambah angka tingkat kemiskinan masyarakat. Namun, masalah seperti ini justru akan dimanfaatkan kembali oleh elit politik sebagai obyek untuk memenuhi kepentingannya. Pada umumnya, masyarakat miskin memiliki akses terbatas dan kemampuan yang lemah pada kegiatan-kegiatan ekonomi (Suyanto, 2001) sehingga hal itu akan menjadi sebab ketidakberdayaan mereka secara materi. Masyarakat yang seperti ini merupakan sasaran strategis bagi elit politik untuk melancarkan aksi dan janji politik. Secara material mereka akan tergantung dan tenggelam dalam alur politik yang dibuat oleh kepentingan elit politik, tanpa mengetahui seperti apa dampak yang ditimbulkan nanti.

Agar terlepas dari alur lingkaran politik yang tidak sehat, masyarakat perlu memiliki kesadaran politik yang tinggi. Kesadaran politik tidak hanya terbatas pada tindakan-tindakan untuk terlibat dalam aktivitas politik, melainkan juga mencakup pengetahuan politik yang benar dan komprehensif. Apabila masyarakat memiliki pengetahuan politik, maka akan baik pengaruhnya pada tindakan-tindakan yang mengarah pada praktik politik sehat. Pengetahuan politik dasar yang harus dimiliki oleh masyarakat adalah mengenai hak-hak politik. Pada dasarnya, hak politik merupakan bagian dari hak-hak yang dimiliki oleh warga negara dan diberikan oleh negara yang menganut asas demokrasi. Hak politik sebagai derivat dari sistem demokrasi harus diakomodir secara baik oleh negara. Namun dalam beberapa kondisi, hak politik belum dipahami secara benar oleh beberapa kelompok masyarakat tertentu, terutama yang berada pada garis kemiskinan dan secara material dapat dimasuki oleh pengaruhpengaruh buruk elit politik dalam menjalankan kepentingannya.

\section{METODE PENELITIAN}

Artikel ini ditulis dengan menggunakan metode studi kepustakaan, menurut Nazir (2003), yakni metode pengumpulan data yang dilakukan dengan menelaah sumber-sumber kepustakaan yang berasal dari buku primer tentang konsep demokrasi dan politik dalam 
berbagai jaman (6 buku), artikel jurnal tentang politik dan teori kemiskinan (4 artikel), maupun disertasi tentang perkembangan demokrasi (1 disertasi). Kemudian, data yang diperoleh dianalisis secara induktif sesuai dengan permasalahan yang berkaitan dengan konseptualisasi hak-hak politik berdasarkan sejarah penggunaan konsep demokrasi pada berbagai jaman.

\section{HASIL DAN PEMBAHASAN}

Agar masyarakat tidak hanyut dalam kepentingan elit politik yang merugikan, maka mereka perlu memiliki suatu pemahaman tentang hakikat hak-hak politik. Hak-hak politik dalam konsep demokrasi dipengaruhi oleh faktor subyektifitas, konteks, kultur sosial politik, dan paham yang dianut oleh masingmasing negara. Pengetahuan tentang hakhak politik dapat ditelusuri dalam sejarah penggunaan konsep demokrasi yang terbagi dalam beberapa periode waktu. Crick (2008) dan Budiardjo (2003) membagi sejarah penggunaan menjadi lima periode, dimulai dari demokrasi yang berlaku jaman Yunani Kuno sampai pada demokrasi konstitusional pada abad ke-20.

Penggunaan Pertama: Konsep Demokrasi Pertama dalam Masyarakat Athena (Abad ke-6 sampai 3 SM). Istilah demokrasi pertama kali muncul dan diartikan secara sederhana oleh Aristoteles dalam bahasa Yunani "demos" dan "cracy". "Demos" yang berarti banyak atau kumpulan orang banyak, dan "cracy" yang mengandung arti aturan. Apabila dua kata tersebut digabungkan, maka demokrasi dapat dimengerti sebagai aturan-aturan yang mengatur sekelompok orang banyak. Di sisi lain, Plato mencoba memberikan kritik kerasnya terhadap demokrasi yang ia sebut lebih sesuai sebagai aturan bagi orang miskin dan bodoh daripada untuk orang yang berpindidikan dan berpengetahuan, seperti idealnya para filsuf. Ia juga meletakkan sebuah perbedaan yang mendasar antara pengetahuan dan pendapat. Pengetahuan mengenai demokrasi sebagai aturan atau bahkan pemerintahan dan pendapat bahwa peraturan itu sebenarnya tidak ada sama sekali. Kemudian, kritik Plato tersebut disempurnakan oleh muridnya, Sokrates. Baginya, pemerintahan yang baik memiliki komposisi yang terdiri dari campuran beberapa elemen yang memiliki kewenangan dan wawasan mengenai beberapa aturan yang kemudian disetujui oleh banyak pihak. Demokrasi dikatakan dapat menjadi sistem terbaik dalam praktik penyelenggaraan negara apabila memuat pengaturan "memerintah dan diperintah secara bergiliran" (Crick, 2008).

Pengaturan tersebut mensyaratkan adanya keseimbangan dalam sistem demokrasi. Di satu sisi terdapat pihak atau kelompok yang memberikan perintah dan di sisi lain ada pihak atau kelompok yang menjalankan perintah. Mekanisme memerintah dan diperintah dilakukan secara bergiliran dan bergantian untuk menghindari praktik aristrokrasi. Crick (2008) beranggapan bahwa terdapat anggapan yang salah tentang aristokrasi yang tumbuh sebagai prinsip yang tidak terkendali dan demokrasi yang dianggap hanya sebatas pengetahuan. Sebagai contoh dalam struktur kehidupan masyarakat Athena yang terdiri dari kelaskelas, pria selalu diutamakan bahkan mereka memiliki hak yang sama hampir di segala hal yang tidak dimiliki oleh perempuan. Kemudian, diskriminasi hak ini kian disadari sebagai sebuah kesalahan. Oleh karena itu mulai pada abad 5 SM, golongan perempuan, masyarakat miskin, orang asing, dan budak mulai dikecualikan dari masyarakat kelas di Athena. Sejak saat itu mereka dapat berpartisipasi dalam membuat keputusan dengan melalui mekanisme debat publik, memiliki hak politik pada pemilihan pejabat dengan memberikan suara, dan menolak serta menggulingkan adanya kekuasaan oleh tiran atau oligarki sempit. 
Farrar (1989) mengungkapkan bahwa sistem demokrasi baru pertama kali dipraktikkan oleh masyarakat Athena pada abad 5 SM walaupun teori tentang demokrasi telah digaungkan ratusan tahun sebelumnya. Politik dalam sistem demokrasi memungkinkan semua golongan warga negara, baik kaya ataupun miskin, untuk mengekspresikan dan mengejar apa yang menjadi tujuanya. Selain itu, juga mendorong warga negara untuk lebih berani menafsirkan tujuan mereka secara politis dan untuk memikirkan tindakannya yang didasarkan pada pertimbangan umum. Kehidupan politik masyarakat Athena saat itu memperlihatkan adanya hubungan saling berbagi, mengutamakan pemahaman diri, dan bukan sekadar perjuangan untuk mencapai kekuasaan politik semata. Setiap warga negara memiliki status politik yang akan memberi dan membentuk ciri pengenal seseorang berdasarkan pada sifat manusia yang senantiasa memiliki rekonsiliasi tujuan pribadi sesuai dengan aturan sosial.

Melalui

sistem demokrasi, masyarakat Athena dibentuk dan anggotanya diberi kebebasan untuk menikmati manfaat dari kehidupan politik dan praktik politik yang terdiri dari beberapa tingkat intensitas. Hal ini menjadi implikasi sebab masih adanya pengaruh nilai-nilai aristokrasi yang membuat partisipasi politik warga negara secara material tergantung pada dominasi seseorang atau kelompok tertentu (contoh: perbudakan). Menanggapi masalah tersebut, partisipasi politik dalam demokrasi masyarakat Athena dibuat menjadi sebuah kelonggaran dari status warga negara. Status yang dimaksud tidak hanya mencakup kepentingan material dari pihak yang memerintah dan diperintah, tetapi juga menyangkut tentang kebebasan yang dimiliki oleh warga negara secara individu.

Penggunaan Kedua: Demokrasi Dibatasi oleh Aturan-aturan Konstitusional
(Abad 17). Sistem demokrasi yang selanjutnya dapat ditemui pada awal Republik Amerika, Republik Roma, dan pada republikan Inggris dan Belanda abad 17. Prinsip demokrasi yang digunakan pada dasarnya masih mengadaptasi teori demokrasi Aristoteles, namun ditambah dengan sedikit penekanan. Demokrasi merupakan campuran dari beberapa unsur atau elemen pemerintahan yang memiliki kewenangan untuk membuat aturan. Namun, demokrasi pada masa ini ditekankan oleh adanya pengaruh undangundang konstitusional yang hanya dapat disusun dan diubah dengan menggunakan prosedur khusus, bukan prosedur yang hanya didasarkan pada perolehan suara terbanyak. Bahkan, elemen-elemen yang terdapat dalam demokrasi pun dapat memberikan pengaruh yang besar kepada negara dengan terlibat dalam prosedur pembuatan dan pengubahan undangundang (Crick, 2008).

Konsep demokrasi yang digunakan pada masa ini hampir mendekati konsep demokrasi modern Patrick (1994) yang memiliki pengertian bahwa penyelenggaraan pemerintahan dalam demokrasi didasarkan pada aturan hukum yang diharapkan dapat mencegah terjadinya kesewenang-wenangan dan penyalahgunaan kekuasaan. Aturan hukum bersifat mengikat dan melindungi semua orang dalam negara dan tidak ada seorangpun, baik kepala lembaga eksekutif maupun ketua parlemen, yang kedudukannya berada di atas undangundang. Demokrasi pada dasarnya mengakui dan membatasi kekuasankekuasaan pemerintah. Kekuasaan pemerintah dan aturan hukum merupakan fondasi dasar konstitusionalisme dalam pemerintahan demokratis.

Jones (1999) menjelaskan bahwa dalam demokrasi yang berada di bawah hukum konstitusional, terdapat hubungan yang tidak biasa antara paham konstitusionalisme dengan demokrasi. Hak-hak konstitutif demokratis secara 
tidak langsung memberikan beberapa hak kebebasan kepada setiap warga negara. Hak yang dimaksud meliputi hak kebebasan untuk membentuk atau terlibat dalam suatu perkumpulan dan asosiasi, kebebasan untuk mendiskusikan masalah atau suatu hal yang berkaitan dengan urusan publik dan kritik terhadap pemerintah, kebebasan dari upaya penangkapan dan hukuman penjara yang bersifat sewenang-wenang, dan kebebasan dari kewajiban politik seperti membayar pajak dan mengikuti tugas wajib militer yang sebenarnya tidak pernah menjadi subyek dalam keputusan demokratis dan persamaan di depan hukum. Oleh karena itu, tidak ada golongan hak istimewa dalam istilah bidang hak dan kewajiban hukum maupun politik. Politik dalam sistem demokrasi dijalankan dan didasarkan pada aturan-aturan konstitusional. Setiap warga negara memiliki hak dan kebebasan dalam politik yang sama, namun keduanya dibatasi oleh aturan hukum dan kekuasaan pemerintah.

Penggunaan Ketiga: Demokrasi untuk Melawan Penindasan Politik dari Sistem Monarki Absolut (Abad ke-17). Teori demokrasi Aristoteles kian mengalami perkembangan seiring dengan meluasnya praktik demokrasi yang digunakan dalam pemerintahan. Untuk selanjutnya, demokrasi dapat ditemukan pada masa Revolusi Perancis (1789-1799) dan dalam tulisan Jean Jacques Rousseau yang berjudul "Discourse on The Origin and Foundations of Inequality". Tulisan tersebut berisi tentang filsafat politik mengungkapkan argumen-argumen untuk melawan kekuasaan sewenang-wenang dari masyarakat Eropa yang menerapkan sistem monarki absolut. Menurutnya, kebebasan seorang individu dapat hancur ketika ia memasuki masyarakat. Di dalam masyarakat akan ada kelompok kuat yang senantiasa memanipulasi kelompok lemah dan kemudian membenarkan kekuasaan yang sewenang-wenang itu melalui argumen-argumen palsu mengenai keadilan. Oleh sebab itu, ia menekankan akan pentingnya melakukan pembelaan terhadap peniadaan penindasan politik untuk membangun kembali kebebasan individu (Revitch \& Thernstrom, 2005).

Dalam konsepsinya, J.J. Rousseau mengungkapkan pandangannya bahwa terlepas dari latar belakang pendidikan dan kekayaan, setiap orang memiliki hak untuk terlibat dalam urusan negara. Selain itu, pengutamaan terhadap kebaikan dan kepentingan bersama dipahami sebagai sebuah jalan yang baik yang didasarkan pada hati nurani dan pengalaman warga negara secara pribadi. Kemudian, pandangan ini memberikan pengaruh positif bagi pembebasan kelas atau bangsa yang semula mengalami pengabaian atau penindasan. Namun dalam peristiwa Revolusi Perancis, muncul berbagai slogan yang menuntut "kedaulatan rakyat" sebagai respon karena kurangnya perhatian pemerintah terhadap kebebasan individu. Masalahnya terletak pada kedaulatan yang dilaksanakan oleh orangorang yang tidak memiliki kewenangan untuk melakukannya (Crick, 2008).

Penggunaan Keempat: Jaminan HAM untuk melindungi Manusia dari Tindakan yang Sewenang-wenang. Sejarah penggunaan terakhir ditemukan dalam konstitusi Amerika, beberapa konstitusi di Eropa pada abad 19, serta dalam konstitusi Jerman Barat Baru dan Jepang yang mengikuti Perang Dunia II (1939-1945) (Crick, 2008). Dalam penggunaan ini, demokrasi diartikan sebagai keseluruhan orang yang pada dasarnya dapat menjadi warga negara yang aktif apabila masingmasing dari mereka memiliki sikap kepedulian terhadap negaranya. Akan tetapi di samping itu, mereka juga harus secara bergantian saling menghormati persamaan hak anggota warga negara yang telah diatur menurut tata urutan aturan hukum yang telah didefinisi, dilindungi, dan dibatasi oleh hak-hak. Oleh karena itu, definisi demokrasi yang saat ini dapat dipahami merupakan hasil 
peleburan gagasan dari kekuatan yang dimiliki oleh masyarakat serta gagasan terhadap jaminan hukum atas hak-hak individu. Namun, peleburan ini dapat menimbulkan kekacauan. Usaha yang harus dilakukan adalah dengan menggabungkan gagasan kekuatan masyarakat dan jaminan hukum atas hakhak individu.

Menyikapi hal ini, Jones (1999) menyampaikan gagasannya bahwa diperlukan suatu definisi yang tepat untuk menyatakan kondisi minimal bagi sebuah sistem pemerintahan untuk memperhitungkan demokrasi. Definisi ini dinyatakan karena pada dasarnya mengikuti: dalam sebuah demokrasi, keputusan masyarakat yang penting terletak pada pertanyaan tentang di mana hukum dan politik bergantung. Secara langsung maupun tidak langsung, sejak opini publik secara resmi dinyatakan oleh warga negara dalam komunitasnya, maka hal ini akan menjadi benteng pemisah bagi orang yang mempunyai hak politik sama.

Demokrasi pada abad ke-19 ditekankan kepada pembebasan manusia terhadap berbagai bentuk kekuasaan yang sewenang-wenang, baik dalam bidang politik maupun agama. Pada masa ini mulai muncul adanya jaminan terhadap hak asasi manusia. Jaminan terhadap HAM ini bertujuan untuk mengurangi ketegangan yang terjadi antara warga negara dan negara (Budiardjo, 2003). Sejalan dengan hal itu, Almond \& Verba (1989) menjelaskan bahwa dalam sebuah negara demokratis yang anggotanya terdiri dari warga negara aktif, ketegangan dalam hal kekuasaan pemerintahan dan daya responsifnya sering sekali terjadi. Oleh karena itu terdapat beberapa kriteria sebagai dasar bagi warga negara untuk melakukan sikap responsif terhadap para elit politik antara lain: Pertama, warga negara harus dapat mengekspresikan dan menyampaikan pandangannya terhadap negara agar para elit dapat mengetahui apa yang mereka inginkan. Penyaluran ekspresi dapat dilakukan oleh warga negara melalui berbagai cara, yakni melalui media massa, orasi langsung, maupun melalui kantor perwakilan elit yang terdapat di setiap daerah/kota.

Kedua, warga negara harus terlibat dalam politik agar mereka dapat mengetahui apakah para elit mempunyai daya responsif atau tidak. Tindakan nyata yang dapat secara langsung dilakukan oleh warga negara adalah dengan ikut serta secara aktif dalam kursi pemerintahan, bersama-sama dengan para elit menjalankan program-program pemerintahan. Ketiga, warga negara harus dapat menjadi pengaruh sehingga dapat membuat para elit mempunyai sikap responsif. Ada kalanya dalam bekerja bersama-sama dengan elit, warga negara juga dapat memberi stimulus atau dorongan dan bekerja bersama-sama dengan baik agar dapat mewujudkan sikap responsif terhadap apa yg dibutuhkan oleh warga negaranya.

Penggunaan Kelima: Demokrasi Representatif yang Dibatasi oleh Aturan Konstitusional. Setelah peristiwa Perang Dunia II pada tahun (1939-1945), terjadi perubahan-perubahan besar dalam tatanan sosial dan ekonomi. Demokrasi pada abad ke-20 tidak hanya terbatas pada urusan politik saja, tetapi meluas ke bidang ekonomi sehingga demokrasi kini bersifat ekonomis. Dari dasar ini, negara dituntut untuk dapat bertanggungjawab atas kesejahteraan warga negara dalam bidang ekonomi dan sosial. Bentuk tanggung jawab tersebut tampak melalui usaha negara untuk aktif dalam mengatur urusan ekonomi dan sosial Selain itu, negara juga harus dapat mengakui dan memelihara hak-hak ekonomi dan sosial dengan membentuk standar dasar ekonomi dan sosial. Hal ini merupakan penjabaran dari konsep Rule of Law yang dikenalkan oleh International Commission of Jurists saat menghadiri konferensi di Bangkok tahun 1965 (Budiardjo, 2003). 
Budiardjo menambahkan (2003), dalam konferensi itu pula International Commission of Jurists membuat sebuah rumusan mengenai sistem politik yang demokratis, di mana hak dalam membuat suatu keputusan politik diselenggarakan oleh warga negara melalui perwakilan yang telah dipilih melalu suatu pemilihan bebas. Dari rumusan inilah lahir bentuk demokrasi yang didasarkan pada sistem representatif (perwakilan). Selain itu, International Commission of Jurists juga mengutamakan adanya jaminan perlindungan terhadap hak asasi golongan minoritas dan mayoritas. Kekuasaan yang dipegang oleh mayoritas tetap akan dibatasi oleh aturan konstitusionil untuk menghindari adanya praktik kekuasaan yang sewenang-wenang. Perwakilan yang telah dipilih akan diawasi secara efektif oleh rakyat dalam masa pemilihanpemilihan berkala dengan dasar prinsip kesamaan politik dan jaminan kebebasan politik

Terlepas dari runtutan panjang sejarah penggunaan dan perkembangan demokrasi dalam berbagai lintas waktu dan negara, secara sosiologis, di Inggris masih ditemukan bahwa masyarakat di sana sangat tidak demokratis dalam beberapa konsep dan cara. Jika dibandingkan dengan Amerika Serikat, hal tersebut tampak sangat jauh berbeda, walaupun jumlah warga negara yang aktif dan tingkat partisipasinya masih dalam jumlah yang sedikit. Secara umum hal tersebut menarik, namun sangat membatasi penyelidikan dalam demokrasi langsung, pemungutan suara daerah, panel kewarganegaraan dan suara masyarakat. Di antara pemilihan dan pembicaraan mengenai partisipasi aktif dalam politik, taksirannya jauh lebih rendah sebagai pendukung utama kegiatan nasional.

Secara institusional, merujuk pada demokrasi di Inggris dan Amerika, ketentuan atau prosedur institusional dilindungi oleh hukum dan membolehkan adanya diskusi publik, kebebasan pers dan pemilihan yang adil. Sehingga, baik presiden, pemerintah dan kelompok perwakilan dapat mengubahnya dengan tenang. Aristoteles (Crick, 2008) menambahkan, sebagai bagian dari konsep kehidupan yang baik, untuk memenuhi rasa kemanusiaan kita harus menjadi warga negara yang bersikap baik dalam hubungan politik dengan warga negara lain. Untuk menjadi politis dan untuk hidup dalam sikap yang baik secara otomatis mengandung pengertian bahwa apapun yang diputuskan telah melalui tahap perundingan bersama dan bukan melalui paksaan. Pada dasarnya, politik timbul dalam kehidupan warga negara yang teorganisasi dan mengakui dirinya sendiri untuk menjadi sebuah perkumpulan dari beberapa anggota yang terdiri atas berbagai bangsa, agama, kepentingan, dan tradisi. Dengan kata lain, politik demokratis merupakan sebuah alat dalam upaya perdamaian yang dibutuhkan dalam masyarakat industri modern dan setelahnya.

Dalam demokrasi modern, politisi dan elit politik harus selalu menyadari bahaya dari adanya percobaan untuk menolak dan melawan pendapat publik. Selain itu, bahaya lain yang juga harus disadari adalah tindakan dalam memuji dan mengikuti pendapat publik yang ada pada saat itu dan terjadi indikasi untuk melawan kepentingan umum dan kebaikan bersama yang sudah berlangsung dalam waktu yang sangat lama. Di samping itu, para politisi demokratis harus mempunyai keberanian untuk mempertahankan dan melawan pendapat miring ketika masyarakat umum terdesak oleh pemimpin-pemimpin rakyat.

Demokrasi kadang-kadang membahas tentang apa yang warga negara inginkan, tetapi ada hal lain yang lebih penting dari itu. Kerakyatan dapat timbul dari kegagalan dari institusi menengah dan terampil untuk mempertimbangkan pendapat asli. Bahkan partai politik, presiden, perdana menteri lebih sering 
muncul untuk melindungi poros utama pemerintahan dan institusi politik negara sebagai miliknya dibandingkan untuk tampil sebagai kepercayaan masyarakat. Oleh karena itu, Dahl (1998) dalam pendapatnya mengungkapkan beberapa karakteristik yang terdapat dalam institusi politik demokrasi modern antara lain sebagai berikut: 1) Pejabat terpilih yang dapat mengontrol keputusan-keputusan yang dibuat oleh pemerintah; 2) Memilih perwakilan rakyat yang bebas, pemilihan umum yang adil dan berjangka; 3) Kebebasan berekspresi dalam hal-hal yang bersifat politik tanpa takut dihukum; 4) Akses terhadap sumber informasi alternatif dan independen; 5) Otonomi terhadap asosiasi, bahwa warga negara harus bebas untuk menggabungkan tujuan yang luas secara bersama. Di dalamnya mencakup tujuan dalam hal agama, kelompok kepentingan dan partai politik; 6) Kewarganegaraan khusus, bahwa secara permanen tidak ada seorangpun penduduk dalam suatu negara yang menolak hak yang tersedia untuk warga negara.

Institusi politik yang dimiliki oleh negara demokrasi modern tidak memiliki arti apapun apabila tidak didukung oleh partisipasi politik warga negara. Memberikan suara saat pemilihan umum kepada perwakilan calon elit merupakan salah satu bagian dari partisipasi politik. Warga negara dapat secara aktif maupun pasif memberikan kontribusinya dalam membangun keberlangsungan demokrasi di negaranya. Partisipasi politik warga negara pada dasarnya muncul sebagai bentuk perwujudan dari hak-hak politik yang dimiliki oleh setiap individu. Tidak ada satu orangpun yang tinggal pada suatu wilayah yang menolak diberi hak-hak politik sebagai individu dalam suatu negara. Semua orang menerima dan menggunakan hak-hak tersebut sebagai upaya untuk mempertahankan eksistensinya dalam upaya untuk mempertahankan hidup.

$$
\text { Janoski dan Gram (2002) }
$$

menjabarkan secara rinci mengenai konsep hak politik, yang mengacu pada partisipasi warga negara dalam arena umum dan juga secara prosedural. Hak politik termasuk juga hak warga negara untuk memberi suara dalam pemilihan dan berpartisipasi dalam proses politik. Mereka juga terlibat dalam prosedur pemilihan calon-calon legislatif, membuat dan menyusun aturan/hukum baru, dan bekerja di kantor pemerintahan. Hak politik untuk organisasi mungkin terdiri dari cara hukum untuk meningkatkan dana kampanye, melakukan konsultasi dengan legislator pada proses pengajuan, menghitung jumlah kandidat politik, dan melobi beberapa aturan-aturan khusus. Pada akhirnya hak politik termasuk dalam hak oposisi, hak perlindungan, hak untuk melakukan ptotes dan demonstrasi, dan hak untuk memiliki akses atas informasi dari pemerintah, dan kemampuan untuk memimpin penyelidikan publik.

Hak-hak politik merupakan salah satu hak kewarganegaraan yang memberikan kebebasan bagi individu untuk menampilkan peran sertanya dalam kegiatan-kegiatan negara. Hak-hak ini oleh Janoski dan Gram (2002) secara umum dibagi menjadi 4 (empat) kelompok yang terdiri atas hak personal atau hak individu, hak organisasi, dan hak keanggotaan, dan hak untuk mendeterminasi diri sendiri. Hak-hak personal merupakan hak yang diberikan kepada individu memberikan suara dalam pemilihan pada calon elit politik yang akan dipilih. Lalu dapat juga dilakukan dengan mendukung jabatan pemerintahan dengan cara menjadi anggota legislatif atau eksekutif atau hanya sekedar memberi kepercayaan kepada elit politik dalam menjalankan tugas perwakilannya. Selain itu terdapat juga hak untuk memberi sanggahan terhadap pemerintah apabila mereka dirasa tidak dapat lagi mewakili warga negara dalam menjalankan kekuasaan negara. Selain hak yang diberikan secara personal, juga 
terdapat kelompok hak organisasi. Hak ini meliputi hak untuk menentukan bentuk dan tujuan dari partai politik yang harus sesuai dengan tujuan negara, hak bentuk kerjasama dalam perdaganagan dan ekonomi, hak sosial untuk melakukan gerakan atau perubahan atau bahkan perlawanan pada pemerintah apabila mereka menyalahgunakan wewenang dan kekuasaan, hak kelompok untuk menghimpun dan menyampaikan sanggahan kepada pemerintah, dan hak budaya atau kaum minoritas. Kelompok hak yang ketiga adalah hak keanggotaan. Hak-hak keanggotaan meliputi hak-hak yang diberikan kepada imigran dan penghuni laut, hak untuk mengajukan naturalisasi, hak asilum, dan hak budaya. Dan yang terakhir, adalah hak untuk mendterminasi diri sendiri. Hak ini ditujukan kepada kelompok daerah, etnis, atau rasial yang mengklaim diri mereka sebagai bangsa yang harusnya dapat merdeka dan berdiri sendiri dengan kedaulatan.

Hak-hak politik yang diberikan oleh warga negara dijadikan sebagai sebuah dasar untuk mewujudkan partisipasi politik. Untuk meningkatkan tingkat partisipasi politik, maka ada beberapa bidang atau aspek yang harus menjadi perhatian untuk dikembangkan. Menurut Normann (2007), pengembangan bidang partisipasi mencakup area jaringan, persekutuan, pengembangan koalisi, dan lain-lain. Meningkatkan tingkat partisipasi warga negara sama juga halnya dengan upaya untuk meningkatkan demokrasi. Dalam istilah demokrasi, struktur pemerintah harus dapat dikira-kira pada kemampuan mereka untuk menguasakan seluruh kepentingan dan tantangan yang diberikan oleh warga negara, dan tidak boleh membiarkan satupun agenda politik, dominasi dan marginalisasi agenda politik lain.

\section{SIMPULAN}

Demokrasi merupakan sebuah istilah yang memberi pengaturan kelembagaan ataupun kewenangan individu dalam berikap demokratis. Demokrasi tidak dapat lepas dari praktik politik, karena keduanya memiliki hubungan seperti dua sisi mata uang koin yang tidak dapat saling lepas. Untuk mewujudkan kehidupan politik yang sehat, warga negara perlu memiliki kesadaran politik yang tidak hanya terbatas pada perwujudan tindakantindakan politik, melainkan juga pada pengetahuan yang mendasar tentang politik, seperti hak politik. Hak politik dapat dipahami berdasarkan sejarah penggunaan konsep demokrasi dalam berbagai periode waktu. Periode pertama penggunaan konsep demokrasi telah ada sejak jaman Yunani Kuno dalam praktik kehidupan masyarakat Athena. Demokrasi pada masa ini merupakan campuran dari beberapa elemen pemerintahan dan menekankan adanya kebebasan yang dimiliki oleh individu. Penggunaan konsep demokrasi pada periode kedua, yakni demokrasi yang pelaksanaannya dibatasi oleh aturan-aturan konstitusional untuk mencegah terjadinya kekuasaan yang sewenang-wenang. Selanjutnya, konsep demokrasi pada periode ketiga diarahkan sebagai bentuk perlawanan dari praktik monarki absolut yang melakukan penindasan politik kepada warga negara. Pada periode keempat, demokrasi memberikan jaminan terhadap hak asasi manusia agar warga negara tidak mengalami tindakan sewenang-wenang dan untuk meredakan ketagangan yang terjadi antara warga negara dan negara. Terakhir, pada periode kelima, demokrasi dijalankan dengan sistem representatif walaupun kekuasaannya tetap dibatasi oleh aturan-aturan konstitusional.

\section{DAFTAR PUSTAKA}

Almond, G. \& Verba, S. (1989). The Civic Culture: Political Attitudes and Democracy in Five Nations. California: Sage Publications, Inc.

Budiardjo, M. (2003). Dasar-Dasar Ilmu Politik. Jakarta: PT. Gramedia Pustaka Utama.

Crick, B. (2008). Democracy. Dalam Arthur, J., Davies, I. \& Hahn, C. (Eds.), Sage Handbook of 
JPPUMA: Jurnal Ilmu Pemerintahan dan Sosial Politik UMA (Journal of Governance and Political Social UMA), 6 (2) (2018): 132-141.

Education for Citizenship and Democracy. London: Sage Publications, Ltd.

Dahl, R. A. (1998). On Democracy. New Haven \& London: Yale University Press.

Farrar, C. (1989). The Origins of Democratic Thinking: The Invention of Politics in Classical Athens. Cambridge: Cambridge University Press.

Janoski, T. \& Gran, B. (2002). Political Citizenship: Foundations of Rights. Dalam Ingin, E. I. \& Turner, B. S., Handbook of Citizenship Studies. London: Sage Publications, Ltd.

Jones, P. \& Weale, A. (Eds). (1999). Democracy: Issues in Political Theory. New York: ST. Martin's Press, Inc.

Nazir, M. (2003). Metode Penelitian. Jakarta: Ghalia Indonesia.
Normann, R. (2007). Democarcy in Development: $A$ Critical View on Regional Governance (Disertasi doktor, Norwegian University of Science and Technology). Tapir Uttrykk.

Revitch, D. \& Thernstrom, A. (eds.). (2005). Demokrasi: Klasik dan Modern - Tulisan Tokoh-tokoh Pemikir Ulung Sepanjang Masa. (Terjemahan Hermoyo). Jakarta: Yayasan Obor Indonesia. (Edisi asli diterbitkan tahun 1992 oleh Harper Collins Publishers, Inc.)

Sunarso. (2007). Pendidikan Politik dan Politik Pendidikan. Jurnal Civics, 4(2): 19.

Suyanto, B. (2001). Kemiskinan dan Pemberdayaan Masyarakat Miskin. Masyarakat, Kebudayaan, dan Politik, Tahun XIV, No. 4: 25-42. 